\title{
Effect of Agricultural Residues Based-Compost on the Yield of Amaranthus hybridus L. (Amaranthaceae) in Gbado-Lite City, Nord-Ubangi (Democratic Republic of the Congo)
}

\author{
Koto-Te-Nyiwa Ngbolua ${ }^{1,2,3}$, *, Zuangbo Innocent ${ }^{1}$, Molongo Médard ${ }^{1,3}$, Masengo \\ Ashande Colette ${ }^{3,4}$, Djolu Djoza Ruphin ${ }^{3,4}$, Yabuda Honoré ${ }^{1,3}$, Gédéon Ngiala Bongo ${ }^{2}$, \\ Gbolo Zoawe Benjamin ${ }^{2}$, Monde-Te-Kazangba Godefroid ${ }^{4}$ \\ ${ }^{I}$ Faculty of Agricultural Sciences, University of Gbado-Lite, Gbado-Lite, Democratic Republic of the \\ Congo \\ ${ }^{2}$ Department of Biology, Faculty of Science, University of Kinshasa, Kinshasa, Democratic Republic of \\ the Congo \\ ${ }^{3}$ Ubangi-BioXplore Project, University of Gbado-Lite, Gbado-Lite, Democratic Republic of the Congo \\ ${ }^{4}$ Department of Environment Sciences, Faculty of Science, University of Gbado-Lite, Gbado-Lite, \\ Democratic Republic of the Congo \\ ${ }^{5}$ Faculty Institute of Agricultural Sciences, Yangambi, Democratic Republic of the Congo \\ jpngbolua@unikin.ac.cd
}

\begin{abstract}
An experimental study was conducted in Gbado-Lite city to develop composts from peanut (Groundnut) and maize residues alone or combined. The study found that plots modified with compost based on peanut (Groundnut) residues combined with corn residues are of good quality compared to non-waste compost combined and unamended plots as indicated by the average values of plant height $(91.9 \pm 0.79 \mathrm{~cm} v s .54 .0 \pm 1.35 \mathrm{~cm})$, diameter at

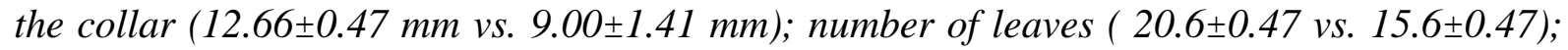
leaf lengths $(23.5 \pm 1.17 \mathrm{~cm}$ vs. $19.4 \pm 1.92 \mathrm{~cm})$; leaf widths $(7.32 \pm 0.44 \mathrm{~cm}$ vs. $6.34 \pm 0.68 \mathrm{~cm})$ yield per hectare ( $22.63 \pm 0.67 \mathrm{~T} / \mathrm{ha}$ vs $11.51 \pm 2.85 \mathrm{~T} / \mathrm{ha})$. It is therefore desirable that compost be characterized from a physical-chemical point of view ( $\mathrm{pH}$, minerals, C/N ratio, etc.) and considers the production of other plants grown on this substrate in order to assess its effectiveness.
\end{abstract}

Keywords: composting; biological agriculture; vegetable production; leafy vegetables; Democratic Republic of the Congo

\section{Introduction}

From times immemorial, human nutrition has always been based partially on the consumption of some vegetables of which crops date from the ancient time because of their nutritional, therapeutics and ritual values (Bukatuka et al., 2016; Tchatchambe et al., 2017).

For the past 30 years, the soil fertility and crop yields have declined in Africa due to the climate change, which cause the loss of nutrients by leaching, erosion, improper harvest that does not follow the offset of natural process and the intake of manure. Despite all this degradation, the demography of population is increasing (high rate of birth) (Bangata et al., 2013a). However, vegetable crops respond specifically to local conditions of temperature and sunstroke while they are also demanding on the soil physico-chemical characteristics which need to be rich in organic matters and well drained (Pallo \& Sawadogo, 2010).

In tropical conditions where soil fertility is fleeting, vegetable yields are less appreciated. This is why most researchers use chemical or organic fertilization to solve this problem (Bangata et al., 2013b; Bosanza et al., 2017). However, the nature of raw materials used to make composts to fine soil and fertilize crops is a limiting factor, especially since these crops are sensitive to the quality of the composts (Aristil, 2019). Moreover, the organic farming system constitutes the best alternative to the use of fertilizers at the Amaranthaceae family level. The aim of the current research was to assess the effect (impact) of agricultural by-products based-compost on Amaranthus hybridus L. Specific objectives are: (i) to 
appreciate the diameter at the collar and height of the plant, (ii) to measure the length and width of leaves and (iii) to assess the yield based on raw material used for composting. The choice of amaranth is justified by the food preference by the basic community, it is an easy vegetable to grow, and it can be prepared in various dishes.

\section{Material and Methods}

\subsection{Study Area}

This study was carried out in Gbadolite city (Nord-Ubangi Province, Democratic Republic of the Congo) from 01/04 to 15/05/2014. Gbadolite city is located in the Ubangian eco-region, a subgroup of Northeastern Congolian lowland forests. This eco-region is one of the 200 globally priority terrestrial eco-riogins known as the "G200" (Ngbolua, 2018; Ngbolua et al., 2018; Ngbolua et al., 2019a, b, c).

\subsection{Plant Material}

The plant material used for this study was amaranth seeds produced locally which was obtained from farmers. The choice of this crop was just because it is the preferred basic food by the local population and it used as medicine for breastfeeding women. However, it is an easy vegetable to cook.

\subsection{Methods}

\section{a. Composting of maize and Groundnut Crop Residues}

Composting is a more or less controlled process of decomposition and processing of biodegradable organic waste from plant and/or animal origin. This biodegradation is usually performed under the action of decomposing aerobic microorganisms (Ake et al., 2018).

The composting technique was used to produce composts as follows:

- Three pits sized as follows: $7.0 \mathrm{~m}$ deep, $1.5 \mathrm{~m}$ long, $0.5 \mathrm{~m}$ dropper, and they were covered;

- Two specific plant species were chosen namely groundnut and maize crop residues and these residues were cut in small pieces;

- Three composters were used as follows: the first for groundnut residues, the second for maize residues and the last for the mixture of both;

- The burying was performed properly so that each $30 \mathrm{~cm}$ layer of the plant waste retained, ash, dung and a layer of soil had to be added in order to facilitate the proliferation of microorganisms' decomposers.

Five months later, the composts were matured.

\section{b. Culture Techniques}

The experimental device chosen was the casualized blocks with three repetitions, each of which consisted of four treatments (T0: control plot ie without amendment;

T1: Compost made with groundnut residue; T2: compost made with maize residue and T3 compost made from the mixture of both residues. Each flowerbed has a $1.20 \mathrm{~m} \mathrm{x} 4 \mathrm{~m}$ or $4.8 \mathrm{~m} 2$.

The treatment consists of $30 \mathrm{~kg}$ of compost spread per flower bed as appropriate; the local variety of amaranth has been germinated and then transplanted to $20 \mathrm{~cm}$ x $20 \mathrm{~cm}$ spreads and some culture techniques were applied notably watering (morning and evening) as well as weeding and suckering. 


\subsection{Observing Parameters}

The following parameters were observed: the height of the plant, the diameter at the collar, the number of leaves, the length of leaves, the width of leaves and the yield and ton yield per hectare.

\subsection{Experimental Design}

The experimental device selected was the casualized blocks with three repetitions, each consisting of 4 treatments each occupying an area of $1.20 \mathrm{~m} \mathrm{x} 4 \mathrm{~m}$ or $4.8 \mathrm{~m} 2$ as revealed in figure 1 below.

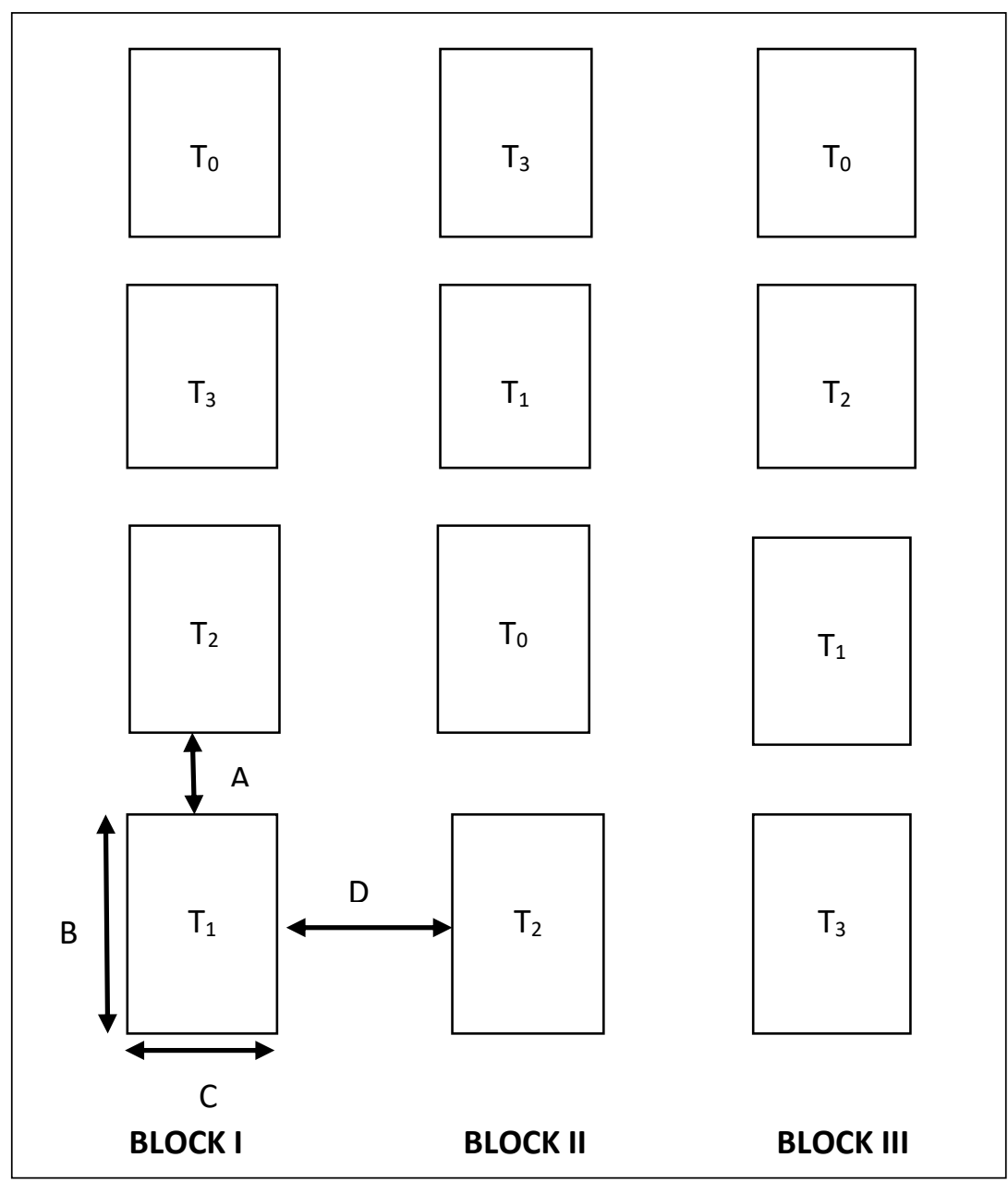

Figure 1. Experimental Field Design

(T0: Control, unamend plots; T1: Groundnut crop residues based-compost; T2: Maize crop residues based-compost; T3: Groundnut and maize crop residues based-compost; A: 0.5 m; B: $4 \mathrm{~m} ; C: 1.2 \mathrm{~m} ; \mathrm{D}: 1 \mathrm{~m}$ ) 


\section{Discussion}

\subsection{The Height of Plants}

Figure 2 gives the average height of plants.

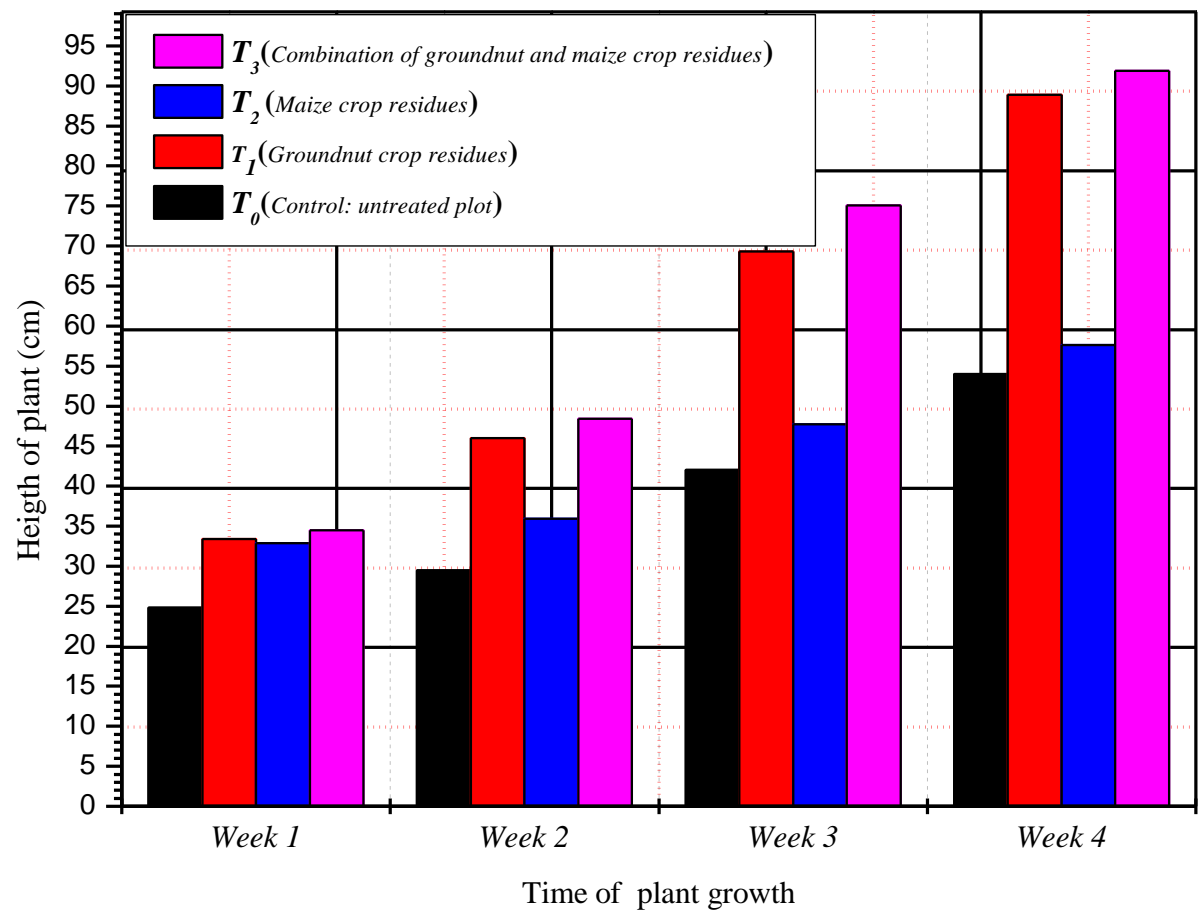

Figure 2. Weekly Evolution of Plant Growth (cm) in Relation to Composts

This figure shows that plants transplanted on control substrate reached a height of 54.00 $\mathrm{cm}$ after one month, but those installed on the compost-enriched substrate groundnut and maize crop residues were $91.9 \mathrm{~cm}$ height. This means that compost as a valuable organic material is the source of minerals responsible for the growth including nitrogen (Ake et $a l$., 2018, 2018). It emerges that the evolution of growth was side by side at the beginning of the vegetation and grew in size at the third week because during this period the radicular apparatus became powerful to fulfill its physiological function by emitting nurturing roots for good growth (Kimuni et al., 2014). This growth is stimulated by the synergistic combination of compost based on the mixture of groundnut and maize crop residues because of their enrichment in nitrogen and phosphorus (Mrabet et al., 2011).

However, the vegetative growth of amaranth plants, although improved by compost input, was directly proportional to the nature of composts (Kimuni et al., 2014). The positive effect of compost on plant growth is mainly due to improvements in the physical, chemical and biological qualities of the soil, the rate of nutrient diffusion and the water retention capacity.

It is known that compost does not only add organic matter to the soil but also trace elements like iron, manganese, copper, zinc and boron which are necessary for the plant growth (Mrabet et al., 2011). It was observed that no plant has reached the height of $1.5 \mathrm{~m}$.

\subsection{The Diameter of the Collar}

The determination of collar diameter $(\mathrm{mm})$ is presented in table 1 . 
Table 1: Determination of the diameter of the collar

\begin{tabular}{lcccc}
\hline \multirow{2}{*}{ Block } & \multicolumn{4}{c}{ Treatments } \\
\cline { 2 - 5 } Block I & $\mathrm{T}_{0}$ & $\mathrm{~T}_{1}$ & $\mathrm{~T}_{2}$ & $\mathrm{~T}_{3}$ \\
Block II & 7 & 12 & 8 & 13 \\
Block III & 10 & 10 & 11 & 12 \\
\hline Average & 10 & 11 & 12 & 13 \\
SD & 9 & 11 & 10.333 & 12,66 \\
CV $(\%)$ & 0.16 & 0.07 & 0.16 & 0,47 \\
\hline
\end{tabular}

(Legend: $T_{0}$ : Control, unalmond plots; $T_{1}:$ groundnut crop residues; $T_{2}:$ Corn crop residues; $T_{3}$ : Groundnut and maize crop residues)

As observed in the table above, the collar diameter of plants follow the same pattern as the height of plants. The most robust subjects $(12.66 \mathrm{~mm})$ were obtained from the T3 treatment where there was a mixture of both residues compared the control $(9.00 \mathrm{~mm})$. This higher response is for sure related to the combined action of improving soil properties and mineralized nutrients as reported in the literature (Kimuni et al., 2014). The ANOVA showed that the coefficient of variation remains below $50 \%$ i.e. no heterogeneity between treatments.

\subsection{Number of Leaves Issued}

Table 2 presents the weekly count of leaf growth.

Table 2. Average number of Leaves Issued under Different Treatments

\begin{tabular}{lcccc}
\hline Block & \multicolumn{4}{c}{ Treatment } \\
\cline { 2 - 5 } & $\mathbf{T}_{\mathbf{0}}$ & $\mathbf{T}_{\mathbf{1}}$ & $\mathbf{T}_{\mathbf{2}}$ & $\mathbf{T}_{\mathbf{3}}$ \\
\hline Block I & 15 & 20 & 17 & 21 \\
Block II & 16 & 19 & 20 & 20 \\
Block III & 16 & 19 & 18 & 21 \\
\hline Mean & 15,6 & 19,3 & 18,3 & 20,6 \\
SD & 0,47 & 0,47 & 1,25 & 0,47 \\
CV (\%) & 3.01 & 2.44 & 6.80 & 2.28 \\
\hline
\end{tabular}

(Legend: $T_{0}$ : Control, unalmond plots; $T_{1}:$ groundnut crop residues; $T_{2}$ : Corn crop residues; $T_{3}$ : groundnut and maize crop residues)

From the above table, it is observed that effects of organic fertilizers were higher for the remaining of vegetative parameters compared to the unfertilized control soil. These effects are believed to be related to the combined action of improved soil properties and nutrient mineralization (Kimuni et $a l ., 2014$ ). The coefficient of variation is greater than $50 \%$, i.e. the treatment is homogenous.

\subsection{Leaf Length $(\mathrm{cm})$}

The leaf length of the amaranth is presented in the table below.

Table 3. Leaf length $(\mathrm{cm})$

\begin{tabular}{lllll}
\hline Blocks & \multicolumn{4}{c}{ Treatments } \\
\cline { 2 - 5 } & $\mathrm{T}_{\mathbf{0}}$ & $\mathrm{T} \mathbf{1}$ & $\mathrm{T} \mathbf{2}$ & $\mathrm{T} \mathbf{3}$ \\
\hline Block I & 16.8 & 20.66 & 20.7 & 22.44 \\
Block II & 21.32 & 23.98 & 20.26 & 25.16 \\
Block III & 20.18 & 22.66 & 20.68 & 23.04 \\
\hline
\end{tabular}




\begin{tabular}{lllll}
\hline Mean & 19.4 & 22.4 & 20.6 & 23.5 \\
SD & 1.92 & 1.36 & 0.20 & 1.17 \\
CV (\%) & 9.88 & 6.08 & 0.98 & 4.96 \\
\hline
\end{tabular}

(Legend: $T_{0}:$ Control, unalmond plots; $T_{1}$ : Groundnut crop residues; $T_{2:}$ Maize crop residues; T3: Groundnut and maize crop residues)

It was observed that the length of amaranth in soil modified in compost based on groundnut and maize crop residues significantly produced a higher number of leaves than the control. At $30 \mathrm{~kg}$ of compost from groundnut and maize crop residues, the number of leaves obtained is 23 leaves per plant while in the absence of compost; only 19.43 leaves were obtained i.e. a difference of $17.5 \%$. These findings are similar with those of Mrabet et al. (2011) who also reported that the number of leaves produced would be relatively different from the control. The coefficient of variation is greater than $50 \%$ showing that there is homogeneity for this treatment.

\subsection{Leaf Width (cm)}

Table 4 presents the measure of leaf width parameters.

Table 4. The Leaf Width $(\mathrm{cm})$ of Amaranth

\begin{tabular}{lcccc}
\hline \multirow{2}{*}{ Blocks } & \multicolumn{4}{c}{ Treatments } \\
\cline { 2 - 5 } & $\mathrm{T}_{\mathbf{0}}$ & $\mathrm{T}_{\mathbf{1}}$ & $\mathrm{T}_{\mathbf{2}}$ & $\mathrm{T}_{\mathbf{3}}$ \\
\hline Block I & 5.4 & 6.98 & 6.08 & 7.08 \\
Block II & 6.96 & 5.96 & 6.2 & 7.94 \\
Block III & 6.66 & 6.42 & 6.4 & 6.94 \\
\hline Mean & 6.34 & 6.45 & 6.22 & 7.32 \\
SD & 0.68 & 0.42 & 0.13 & 0.44 \\
CV (\%) & 10.66 & 6.47 & 2.12 & 6.04 \\
\hline
\end{tabular}

(Legend: $T_{0}$ : Control; $T_{1}$ : groundnut crop residues; $T_{2}$ : Maize crop residues; $T_{3}:$ groundnut and maize crop residues)

It was observed that leaf width increased more and more with the origin of composts. The best yields were obtained from plants grown with compost substrates from the treatment where both substrates were mixed. The variance analysis showed that the coefficient of variation remained below $50 \%$, there is heterogeneity between treatments.

\subsection{The Yield in Tons per Hectare (T/ha)}

Table 5 presents extrapolated data in tons per hectare.

Table 5. Yield in tons per hectare (T/ha)

\begin{tabular}{lllll}
\hline Blocks & \multicolumn{4}{c}{ Treatments } \\
\cline { 2 - 5 } & $\mathrm{T}_{0}$ & $\mathrm{~T}_{1}$ & $\mathrm{~T}_{2}$ & $\mathrm{~T}_{3}$ \\
\hline Block I & 7.6 & 19.529 & 13.595 & 22.438 \\
Block II & 8.679 & 19.762 & 12.15 & 21.917 \\
Block III & 14.104 & 20.112 & 15.187 & 23.521 \\
\hline Mean & 11.514 & 19.801 & 14.56 & 22.625 \\
SD & 2.85 & 0.24 & 1.24 & 0.67 \\
CV $(\%)$ & 24.72 & 1.21 & 8.52 & 2.95 \\
\hline
\end{tabular}


From above, it can be noticed that the yields expressed in tons per hectare of this investigation were: $11.514,19.801,14.560$ and 22.625 respectively for the control, because they were enriched with residues from groundnut, maize and groundnut and maize crops.

It is observed that plants, leafy vegetables, have responded favorably to the application of the composts offered by the residues of groundnut crops and residues of groundnut and maize crops, which are rich in nitrogen and phosphorus nitrogen respectively. These matter have therefore increased the yield in useful product, biomass, such was the observation that organic matter contributes to the stability of the physical, chemical and biological conditions of the soil (Kimuni et al., 2014). The crops grown on the types of these soils with organic materials are more resistant to random climatic variations and give stable yields (CIRADGRET, 2009). These results revealed that the association of two composts has produced a synergic effect as single composts alone (Ake et al., 2018).

These results are less than $25 \mathrm{~T} / \mathrm{Ha}$, experimenting with a single crop after 20 days and $50 \mathrm{~T} / \mathrm{Ha}$ by teen making several times after 50 days. Thus, the plants installed on the control plots gave the lowest results. In this study, we recorded a compost contribution to yield in the order of $14.98 \% ; 50 \%$ and $68.55 \%$ respectively compost from corn crop residues, groundnut crop residues and groundnut and corn crop residues. Indeed, studies conducted in the natural environment have shown that local resources such as organic waste, applied to poor tropical soils and acids can provide the nutrients needed for feeding and growing and therefore increase the yield of cultivated plants (Kimuni et al., 2014).

The coefficient of variation is greater than $50 \%$, so there is homogeneity in the different treatments. These results show that crop costs (organic waste) are abundantly present in Gbadolite city and may be a good alternative to mineral fertilizers that do not are not within the reach of the region's farmers.

Table 6. Statistical Analysis

\begin{tabular}{llllll}
\hline $\begin{array}{l}\text { Source of } \\
\text { variation }\end{array}$ & Dl & SCE & CM & Fobs & F $_{\text {tab 0.05 }}$ \\
\hline Treatments & 3.00 & 11.69 & 3.89 & $12.78^{*}$ & 9.55 \\
Blocks & 2.00 & 0.54 & 0.27 & $0.07^{0}$ & 4.303 \\
Error & 11.00 & 2.44 & & & \\
\hline
\end{tabular}

(The difference is significant at the probability threshold 0.05)

The variance analysis reveals a significant difference between the different composts in relation to their origin $(\mathrm{p}<0.05)$. The average comparison using the smallest significant difference test can be summed up as follows: $T_{3}>T_{1}>T_{2}>T_{0}$. This means that among these composts, those from the groundnut and maize residues association is better than the other treatments including the control. The result from grass composts was no different from that of a control plot. However $\mathrm{T}_{3}$ and $\mathrm{T}_{1}$ differ significantly from that of $\mathrm{T}_{0}$, in terms of leaf yield.

\section{Conclusion}

This study was conducted with the aim of developing composts from groundnut and maize residues separately and both mixed. The study found that plots modified with compost based on groundnut residues combined with maize residues are of good quality compared to compost based on uncombined residues and control as revealed by the average plant height values $(91.9 \pm 0.79 \mathrm{~cm}$ vs. $54.0 \pm 1.35 \mathrm{~cm})$, diameter at the collar $(12.66 \pm 0.47 \mathrm{~mm}$ vs. $9.00 \pm 1.41 \mathrm{~mm})$; number of leaves $(20.6 \pm 0.47$ vs. $15.6 \pm 0.47)$; leaf length $(23.5 \pm 1.17 \mathrm{~cm}$ vs. 
$19.4 \pm 1.92 \mathrm{~cm})$ leaf width $(7.32 \pm 0.44 \mathrm{~cm}$ vs. $6.34 \pm 0.68 \mathrm{~cm})$, yield $(5.43 \pm 0.16 \mathrm{~kg} / 2.4 \mathrm{~m} 2$ $22.63 \pm 0.67 \mathrm{~T} / \mathrm{ha}$ vs $11.51 \pm 2.85 \mathrm{~T} / \mathrm{ha}$ ) respectively. It is therefore desirable that the compost has to be characterized from a physico-chemical point of view ( $\mathrm{pH}$, minerals, $\mathrm{C} / \mathrm{N}$ ratio, etc.) and consider the production of other plants grown on this substrate in order to assess its effectiveness.

\section{Acknowledgements}

The authors are indebted to Professor Ngbolua Koto-te-Nyiwa, Rector of the University of Gbado-Lite and Principal investigator of "Ubangi BioXplore" project for the promotion of scientific research on the biodiversity of the Ubangi eco-region.

\section{References}

Ake, H.T.B., Bi, T.T., Denezon, O.D. (2018). Caractéristiques physico-chimiques des composts à base de sous-produits de ferme de Songon en Côte d'Ivoire. International Journal of Biological \& Chemical Sciences 12(1), 596-617.

Aristil, J. (2019). Effets de trois types de fertilisants sur les paramètres végétatifs et productifs du sorgo en Haiti. International Journal of Biological \& Chemical Sciences, 13(2), 720726.

Bangata, B.M., Ngbolua, K.N., Ekutsu, E., Kalonji, M.A. (2013a). Comportement de quelques lignées de riz NERICA en culture de bas-fond dans la région de Kinshasa, République Démocratique du Congo. International Journal of Biological \& Chemical Sciences, 7 (1), 16-24. URL: http://dx.doi.org/10.4314/ijbcs.v7i1.3.

Bangata, B.M., Ngbolua, K.N., Minengu, M., Mobambo, K.N. (2013b). Etude comparative de la nodulation et du rendement de quelques variétés d'arachide (Arachis hypogaea L., Fabaceae) cultivées en conditions éco-climatiques de Kinshasa, République Démocratique du Congo. International Journal of Biological \& Chemical Sciences, 7(3), 1034-1040. URL: http://www.ajol.info/index.php/ijbcs.

Bosanza, J.B.Z., Mongeke, M.M., Kalombo, T.G., Bedi, N.B., Djolu, D.R., Ngbolua, K.N. (2017). Données préliminaires sur le bouturage de Cola acuminata (P. Beauv.) Schott \& Endl. (Malvaceae) dans le Sud Ubangi (République Démocratique du Congo). International Journal of Innovation and Scientific Research, 31(2), 234-240.

Bukatuka, F.C., Ngombe, K.N., Mutwale, K.P., Moni, B.M., Makengo, K.G., Pambu, L.A., Bongo, N.G., Mbombo, M.P., Musuyu, M.D., Maloueki, U., Ngbolua, K.N., Mbemba F.T. (2016). Bioactivity and nutritional values of some Dioscorea species traditionally used as medicinal foods in Bandundu, DR Congo. European Journal of Medicinal Plants, 14 (1), 1-11.

CIRAD-GRET (2009). Mémento de l'Agronome, Ministère des Affaires étrangères, éd. QUAE, pp.471-1028.

Kimuni, N., Kisimba, M., Mwamba, M., Lwalaba, W.L., Kanyenga, L., Ntumba, K., Mpundu, M., Baboy, L. (2014). Effets de doses croissantes des composts de fumiers de poules sur le rendement de Chou de Chine (Brassica chinensis L.) installé sur un sol acide de Lubumbashi. Journal of Applied Biosciences, 77, 6509- 6522.

Mrabet, L., Belghyti, D., Loukili, A., Attarassi, B. (2011). Étude de l'effet du compost des déchets ménagers sur l'amélioration du rendement de Maïs et de la Laitue. Afrique Science 07(2): $74-84$.

Ngbolua, K.N. (2018). Données préliminaires sur la biodiversité du Nord-Ubangi en République démocratique du Congo. Editions Universitaires Européennes, Riga: Latvia. ISBN: 978-613-8-44529-6.

Ngbolua, K.N., Ndanga, A., Gbatea, A., Djolu, R., Ndaba, M., Masengo, C., Likolo, J., Falanga, C., Yangba, S., Gbolo, B., Mpiana, P. (2018). Environmental Impact of Wood- 
Energy Consumption by Households in Democratic Republic of the Congo: A Case Study of Gbadolite City, Nord-Ubangi. International Journal of Energy and Sustainable Development, 3(4), 64-71.

Ngbolua, K.N., Ngemale, G.M., Ashande, M.C., Bamwa, M.N., Ndolete, G.J.P., Djoza, D.R., Libwa, M.B., Bongo, N.G. (2019a). Evaluation of Artisanal Logging Sector in Democratic Republic of the Congo: A Case Study of Peri-urban Forest of Gbadolite City, Nord-Ubangi. International Journal of Plant Science and Ecology, 5(2), 25-30.

Ngbolua, K.N., Nzamonga, G.A., Kundana, G.A., Nzale, M.S., Masengo, A.C., Ndolete, G.J.P., Bongo, N.G., Zakwani, L.N., Libwa, M.T.B., Yangba, T.S., Gerengbo, K.G. (2019b). Knowledge on Non-Timber Forest Products (NTFPs) Marketed in Democratic Republic of the Congo: A Case Study of Gbadolite City and Surroundings, Nord Ubangi. Agricultural and Biological Sciences Journal, 5(1), 20-28.

Ngbolua, K.N., Nzamonga, G.A., Gbatea, K.A., Limbaya, M.T., Mwinja, C.A., Bongo, N.G., Masengo, A.C., Djolu, D.R. (2019c). Knowledge on the Environmental Disaster Occurrence in the Democratic Republic of the Congo: The Case of Flooding and Bushfire in Businga Territory, Nord Ubangi. Asian Journal of Geographical Research, 2(1), 1-15.

Pallo, F.J.P., Sawadogo, N. (2010). Essai de corrélation entre les caractéristiques du climat, de la végétation et des sols au Burkina Faso. International Journal of Biological \& Chemical Sciences, 4(5), 655-663.

Tchatchambe, N.B., Solomo, B.E., Kirongozi, B.F., Lebisabo, C.B., Dhed'a, B.D., Tchatchambe, W.B., Ngombe, K.N., Mpiana, P.T., Mbemba, T.F., Ngbolua, K.N. (2017). Analyses nutritionnelle et toxicologique de trois plantes alimentaires traditionnelles de la Tshopo en République Démocratique du Congo. International Journal of Innovation and Scientific Research, 30(2), 105-118. 